\title{
EKOLOGI SOM KULTURVETENSKAP - EN RADIKAL UTMANING FÖR MUSEERNA
}

\author{
Per Råberg
}

Ett ekologiskt synsätt har explosiva implikationer inte bara därför att ekologin till sitt väsen är en kritisk vetenskap ....... utan också därför att den är en är integrativ och rekonstruktiv vetenskap. Denna integrativa, rekonstruktiva aspekt hos ekologin leder, om man utvecklar alla dess implikationer, direkt in i det sociala tänkandets anarkiska områden. Ty i sista hand är det omöjligt att genomföra en harmonisering av människa och natur utan att skapa ett mänskligt samhälle som lever i varaktig balans med sin naturmiljö.

Murray Bookchin (1965, Post-Scarcity Anarchism)

När ett ekologiskt synsätt fick sitt genombrott $i$ den intellektuella och politiska samhällsdebatten på sjuttiotalet var det bärande idémässiga motivet den kunskapsteoretiska nyorientering som begreppet innebar. Äntligen hade den humanistiska sambällskritiken fätt de suveräna redskapen for sätta fullt ljus på det teknokratiska sambällets växande krissymtom och inleda den stora uppgörelsen med den mekaniska cartesianism ur vilken den moderna sambällskrisen sprungit fram.

\section{DET EKOLOGISKA PARADIGMET}

Den omedelbara inspirationen till det ekologiska idégenombrottet kom med 60talets upptäckt av miljökrisen. Men det var ekologibegreppets vidgning till det sociala området som gav upphov till den intellektuella innovationen. Den centrala nya idén var visionen av samhället som ett livsdynamiskt system. I ett livsdynamiskt system är det människan själv, som organism och kulturvarelse, som är samhällets bärande innehåll. Samhällets uppgift är att ge utrymme för individernas naturliga interaktion med omvärlden och inom sina ramar sörja för den gemensamma välfärden. Den enskilda individens upplevda livskvalitet är det överordnade målet för den sociala planeringen i ett livsdynamiskt system. Detta var en humanistisk tankegång som stod i stark kontrast till de rigida samhällsformer som senmodernismen började uppvisa vid denna tid, och upplevdes av många som en befrielse och ett 
72 löfte. Sin teoretiska inspiration hämtade den nya visionen hos de moderna biovetenskaperna och främst från ekologin. Men sitt främsta sociala uttryck fick visionen $\mathrm{i}$ «den gröna vågen», som var en hel generations protest mot den alienerande storstadskulturen och försök att skapa ett naturanpassat samhällsalternativ.

Det är framför allt den emancipatoriska traditionen $\mathrm{i}$ den moderna ekorörelsens historia som företräder en sådan socialekologisk ståndpunkt (se Robyn Eckersley: Environmentalism and Political Theory, 1992). Med den alternativa visionen kunde man ge precision åt en samhällskritik som intellektuella strömningar hade försökt formulera under decennier utan att lyckas helt (t.ex. den kritiska teorin och kommunitarianismen). Med stöd av de livsdynamiska argumenten kunde man avslöja de människofientliga dragen hos den teknokratiska välfärdsstaten och påvisa hur det segerrika cartesianska paradigmet på kort tid förvandlats till ett hot mot människans civilisation. Den växande globala miljökrisen var det lättast iakttagbara av en serie symtom på ett sjukdomstillstånd i hela samhällssystemet. Men att diagnosticera krisens kärna i den sociokulturella miljön och att bota själva systemkrisen var huvuduppgiften.

Den emancipatoriska ekorörelsen introducerade med sina argument en ny tankefigur i den politiska debatten. Det var en tankefigur som skar tvärs över den traditionella höger-vänsteraxel som vi vant oss att betrakta som huvudlinjen för politisk samhällsanalys. Polerna på den alternativa axeln var i den ena riktningen det alienerade tekniksamhället och i den andra det harmoniska ekosamhället i balans med naturomgivningarna. Både liberalismen och socialismen hade ensidigt valt den teknologiska framstegsvägen och representerade i ekoidealismens ögon ett hot mot en uthållig utveckling. Men vilken form och vilket innehåll skulle det bärkraftiga ekosamhället ges? Det var den underliggande frågan för en alternativ politisk rörelse och en invitation till alla krafter att tävla om utformningen av nya samhällsmodeller. De gröna politiska partierna som bildades i många länder under 70och 80-talen blev den främsta manifestationen av förändringsviljan.

Men det ekologiska perspektivet innehöll en invitation också till en förnyelse av vetenskapernas samhällstänkande. I centrum för det nya vetenskapliga intresse som växte fram under dialog med biovetenskaperna ställdes de interaktiva processerna i lokalsamhällets samspel med sitt geografiska omland. Men det var inte vilka som helst mekaniska eller kausala samspel som intresserade de ekologiska tänkarna. Det var de levande människornas dynamiska interaktion med livsrummet i olika konstellationer. Och det intellektuella intresset för ett livsdynamiskt synsätt var inte någon tillfällig modetrend. Det grundade sig på övertygelsen att den ekologiska interaktionen utgör en ledande princip i de globala livssystemens organisation och därmed är en huvudkälla till en djupare förståelse av människan.

Det är viktiga preciseringar av det moderna ekologibegreppet som jag pekar på. Det är först genom dem som den ekologiska visionen tar form som en fullvärdig aspirant på att företräda ett nytt paradigm, med vars hjälp samhällskrisen kan förklaras och nya livsdugliga alternativ tas fram. 


\section{DEN EKOLOGISKA METODEN}

Det är också i dessa definitioner som en vetenskaplig metodik för att studera den ekologiska livsdynamiken har sin utgångspunkt. Den logiska startpunkten är det autekologiska perspektivet, dvs studiet av den enskilda organismen i dess samspel med sina elementära livsomgivningar. Vilka egenheter kännetecknar individens interaktiva beteende och vilka yttre systemiska spår avsätter förloppet? I vad mån påverkar yttre miljöfaktorer organismen och dess långsiktiga handlingsstrategier? Så lyder några elementära frågeställningar. Till dessa ansluter sig ett demekologiskt perspektiv där interaktionen inom en population och i dess samverkan med omgivningarna är studieområdet. Slutligen följer studiefältet för den systemekologiska interaktionen mellan arter och populationer inom en hel biotop. Detta är en aktivitet som utspelar sig i ett antal skalsteg, med den globala biosfären som den yttersta helheten. Någonstans går en gräns där den biodynamiska aktiviteten övergår till biokemiska och fysikaliska flöden.

Identifieringen av de systemiska helheter i vilka den ekologiska interaktionen organiserar sig är ett genomgående metodiskt tema och har inspirerats av den moderna systemteorin. Ett annat huvudtema är analysen av de nukleära styrfunktioner genom vilka systemen hålls samman kring sina metaboliska processer. Modern cybernetisk teori har gett viktiga impulser till denna typ av undersökningar. Men också den horisontella och vertikala systeminteraktionen, energi- och entropiflödena mellan nivåerna och upprätthållandet av inre och yttre jämvikt är punkter i den vetenskapliga ekologins analyser.
Med den ekologiska metodiken kan många uppslag för studiet av människosamhällets strukturer konstrueras. Men det ekologiska perspektivet har inte uttömt sina aspirationer med detta. Ett kosmo-ekologiskt perspektiv har ibland anlagts och frågan har ställts om också universum kan beskrivas efter livsdynamiska principer av det slag som den biologiska människoekologin använder. Omvänt kan frågan ställas om det bioekologiska systemet ev. återspeglar högre kosmiska organisationsprinciper av fysikalisk eller annan art. Kring dessa teman förs en spekulativ filosofisk diskussion som i sin art ter sig absolut relevant i den kosmiska tidsålder som vi står på tröskeln till (jfr Gaia-hypotesen).

Men minst lika relevant är studiet av livsdynamikens vitala utgångspunkt, dvs de levande organismerna som drivkraft för de interaktiva processerna. Här öppnar sig flera ingångar till ett nytt människostudium, där individens mentala uppbyggnad betraktas som en produkt av en medvetandeevolution som sträcker sig över årmiljonerna. I detta studium kan den avancerade mänskliga nivån endast förstås mot bakgrund av de tidigare stadier som bio-evolutionen passerat och deras fortlevnad i omdanad gestalt i människans medvetande. Detta är en klart vetenskaplig tankegång som, logiskt slutförd, bl.a. innebär ett ifrågasättande av den kategoriska gränsdragning som de samtida natur- och kulturvetenskaperna - från var sin sida företar mellan den mänskliga existensens elementära biologiska och avancerade kulturella former.

Att betrakta den moderna människan som ett ur den bio-ekologiska förhistorien framsprunget väsen - istället för enbart en 
PER R B B R G

74 tidsbestämd kulturprodukt - innebär inte ett förringande av hennes kulturella värde. Den emancipatoriska humanekologins syfte var redan vid tillkomsten det omvända: att återupprätta den höga livskvaliteten i ett genom utvecklingskrafterna banaliserat och alienerat samhällssystem. Den ekologiska visionen tillhandahöll den intellektuella kod med vilken dessa intentioner kunde realiseras ute i samhället och i dess vetenskaper. Och visionen bars fram av en kulturell medvetenhet som gav hopp om att detta kunde ske utan förlust av den kvalitativa kärnan.

\section{DEN EKOCENTRISKA RÖRELSEN}

Hur har då förväntningarna infriats? I vilken utsträckning har det ekologiska paradigmets intentioner realiserats $i$ den politiska sfären, och vilka vetenskapliga resultat har uppnåtts? Dömer vi på basis av en frekvensundersökning av ordet ekologis förekomst i samhällsdebatten får man intrycket att det ekologiska perspektivet har segrat på bred front. Räknar vi projekt, organisationer och institutioner som betecknar sig som humanekologiska talar allt för en betydande framgång. Och anlägger vi funktionella kriterier är det uppenbart att toppinsatser har gjorts under decennier, framför allt på miljöoch naturresursområdet. Dessa insatser på miljöområdet har väckt ett brett intresse som bl.a. demonstrerats i ett antal världskonferenser, senast den i Rio de Janeiro 1992.

Men anlägger vi strängt intellektuella kriterier och värderar insatserna efter de kunskapsteoretiska förväntningar som nämndes inledningsvis, blir svaret ett annat. Det som då faller i ögonen är inte de framstående miljöinsatserna utan den närmast totala avsaknaden av originella initiativ på det sociala och kulturella området, i själva problemkärnan. Det vi då konstaterar är att de ekologiska idealen av många aktörer närmast automatiskt identifieras med miljöfrågorna i samhället, ja handfast förvisas till denna sektor om de skulle våga ge sig in på mer centrala domäner. Med viss förvåning registrerar vi att ekologi i en del grupperingar reducerats till en snäv eko-centrisk dogmatism som avvisar ett samhällsorienterat, antropocentriskt synsätt på samtidskrisen. Det är en hållning som delvis hänger samman med ekorörelsens uppstigande till en maktposition i samhället. Att satsa sektoriellt på miljöfrågorna har (relativt) lätt medfört succé, medan systemkritiska inlägg kunnat räkna med benhårt motstånd. Ett behjärtansvärt men ytligt ekologiskt intresse genomsyrar i dag samhället, men samtidigt har rörelsens udd böjts och kommit att riktas mot dess eget hjärta. De gröna politiska partiernas förvandling från ideologiska kraftcentra till protestpartier utan artikulerad samhällsvision är ett exempel på vart ett haltande ekologiskt engagemang leder.

Denna kritiska kommentar innefattar delvis den humanekologiska riktningen, som ganska nyligen etablerat sig som självständig disciplin i den akademiska världen. Humanekologin har gjort en storstilad insats som introduktör av ekologiska perspektiv inom humaniora och i samhällsvetenskaperna. I allmänhet har man med "ekologi» avsett samhällets yttre miljö- och resursfrågor, och den allvarliga biotiska kris som uppstått kring dem. Humanekologins miljöpatos har betytt oerhört mycket för att öka de kulturveten- 
skapliga ämnenas samhällsobservans och kritiska tänkande. Genom det nya miljöhistoriska ämnet har dessutom en viktig idéhistorisk djupdimension fogats till krisanalysen. Likafullt har ekologibegreppets humanisering knappast inspirerat humanekologerna till att studera kultursamhället som ett ekologiskt system som kan analyseras med hänsyn till sina genuina livsdynamiska egenskaper. Tvärtom kan man observera en avvaktande för att inte säga skeptisk hållning till ansatser som vågat pröva fördjupade kunskapsteoretiska synsätt. Samtidigt har humanekologin med $\sin$ snäva begreppsdefinition ibland uppträtt med universella anspråk som närmast innebär en bannlysning av kvalitativa socialekologiska initiativ.

\section{DEN SOCIOKULTURELLA KRISEN}

När nya riktningar uppstår och reser sina anspråk händer det ibland att verkligheten griper in korrigerande. Vi står idag med facit $i$ hand och konstaterar att den globala miljöförstöringen fortsätter i oförminskat tempo och genom de ekosfäriska hoten (t.ex. ozonskiktets uttunning) har antagit nya dimensioner. Ingen kan längre undgå att se att de hittillsvarande insatserna trots stora uppoffringar haft karaktären av symtomlindring. Krisens grundläggande orsaker i samhällskärnan har man på politisk nivå ännu knappast observerat, och än mindre angripit (ett typiskt exempel är Brundtlandrapporten från 1987).

Samtidigt har de sociokulturella krissymtomen drastiskt tilltagit i styrka och komplikation. Den sociala desintegrationen genom samhällets skaltillväxt, sänkningen av den estetiska livskvaliteten och förlusten av värdeperspektivet i politiken, har utlöst anarkistiska krafter och underblåser en våldsmentalitet som antagit katastrofala proportioner (ungdomsvåldet, de regionala krigen och folkmorden är toppen av ett isberg). Det är tendenser som på sikt kan få tragiska konsekvenser för hela vår civilisation. Är det symtomen på en samhällsupplösning i stor skala som vi är vittne till? Det politiska etablissemanget dementerar bestämt, samtidigt som man i sin okunskap fortsätter nedmonteringen av den civila samhällskärnan och skapar nya mänskliga frustrationer.

Den sociala krisen och miljökrisen är båda utslag av samma paradigmkris och omfattas båda av det nya ekologiska intresset. Men engagemanget för miljöfrågorna kan inte längre tillåtas tjäna som alibi för att slippa ta tag i den sociokulturella krisen. Mot bakgrund av den vidgade hotbilden är det nödvändigt att utan dröjsmål öppna en civilisationskritisk debatt som omfattar också sociosfären och den kulturella dimensionen i det senmoderna samhället. Politiker, medborgare, intellektuella och humanister av alla schatteringar måste inbjudas att delta i denna ursäkta uttrycket - ödesdebatt. Men det är också självklart att en radikal genomlysning sker av vetenskapssamhällets medansvar för situationen och potential att medverka till en förnyelse. Ett givet tema utgör här den rådande obalansen i kunskapsutvecklingen mellan natur- och humanvetenskaperna, vars logiska pendang är obalansen mellan teknologiska och humanistiska värderingar i den politiska sfären. Hur skall dessa obalanser i vetenskaperna och i samhället förklaras, men framför allt avhjälpas? Hur kan vi få en human- och samhällsforskning som förser politikerna med de kunskaper om 
PER R \& B R G

76 samhället och människan som krävs för att vandringen mot en bärkraftig social och kulturell framtid skall kunna inledas?

Att skapa klarhet kring dessa frågor är givetvis $i$ långa loppet den enda realistiska utgångspunkten för att få till stånd också en trovärdig miljö- och resurspolitik och återskapa den rubbade balansen i de globala ekosystemen.

\section{DEN EMANCIPATORISKA RÖRELSEN}

Det är när vi diskuterar denna problembild som den emancipatoriska ekologins idéperspektiv pockar på förnyad uppmärksamhet och prövning. Och när vi företar en sådan prövning konstaterar vi snabbt att konceptet varken är förbrukat eller realiserat. I sin kärna återstår det att omsätta och ter sig mer än någonsin som ett verktyg för den paradigmatiska förändring och kunskapsuppbyggnad som vi väntar på. Men för att uppnå det avsedda syftet krävs att vi äntligen lyfter fram den fundamentala kärnan, som är att lansera en ekologisk människosyn grundad i bio-vetenskaperna och i kunskaper om den organiska livsdynamiken. Det betyder att vetenskapen nu måste fokusera människan själv och hennes interaktion med livsrummet. Men det innebär också att de kommunikativa nätverken som förenar individen med den lokala befolkningen på en bestämd plats blir ett tema för forskningen.

En nyckelroll i det sociokulturella ekosystemet intar individens livsmedvetande. Livsmedvetandet bildar den seismografiskt känsliga kontaktytan mellan den aktiva människan och hennes omvärld. Det omfattar kännedom både om den yttre verklighetens fenomen och den inre verk- lighetens emotiva reaktioner. I ett ekovetenskapligt perspektiv är människans livsmedvetande resultatet av ett evolutionärt förlopp som tar sin begynnelse i de cellulära livsformernas era på planeten. Evolutionsforskningen påvisar hur utvecklingen fortskridit $\mathrm{i}$ en serie paradigmsprång från elementära till mer avancerade stadier, och de främsta indicierna finner vi i organismernas konstitution, med dess skiktning i flera särpräglade nivåer. Livsmedvetandets stegvisa utveckling är troligen förbunden med individens ianspråktagande av allt vidsträcktare horisonter i omvärlden, som fordrat alltmer sofistikerade strategier för att behålla de sociala och ekologiska strukturerna under systemisk kontroll.

Livsmedvetandets yttringar och förvandlingar utgör kärnan i det autekologiska perspektivet. Men till autekologins och det nära livsrummets teman fogar sig studiet av de storskaliga ekologiska samspelen inom människoarten eller med de andra arterna i det biosfäriska rummet. I människans historiska utvecklingsfas har de systemekologiska intentionerna ständigt förverkligats i olika skalor. De kodifieras i en rad geopolitiska begrepp som t.ex. «staden», «regionen» och «nationen». Sitt paradigmatiska värde erhåller de systemekologiska studierna emellertid först om de kopplas till den primära autekologiska eller demekologiska analysen. Försummas denna återkoppling mister studierna omedelbart sitt värde som humanekologisk vetenskap; med rätta bör ansatserna hänföras till vetenskaper som kulturgeografi, antropologi, demografi, klimatologi etc.. 


\section{DEN AKADEMISKA KONTEXTEN}

En viktig fråga är var i vetenskapssamhällets spektrum av ämnen en emancipatorisk humanekologi skall placeras. Det spontana svaret är: varhelst ett insiktsfullt intresse för den vetenskapliga saken och det paradigmatiska dilemmat ger sig till känna. Universitetens nuvarande ämnesorganisation motsvarar bara $i$ begränsad utsträckning kunskapsteoretiska kriterier och är en följd av historiska omständigheter. En pragmatisk hållning till ämneslokaliseringen är därför motiverad.

Om vi utgår från renodlat vetenskapsteoretiska kriterier ger sig en mer nyanserad värdering. Naturvetenskapen framstår som den optimala arenan genom sin tradition för ett empiriskt och uppslagsrikt sökande efter lagbundenheter hos naturprocesserna. Detsamma kan sägas om den moderna biovetenskapen, som har fördelen av en stor förtrogenhet med den organiska livsvärldens villkor. Båda vetenskapsgrenarna har dock genom sin historiska dominans kommit att utveckla en scientistisk enkelspårighet som är ett stort hinder vid studiet av komplexa samhällsprocesser och människan som kulturvarelse.

Samhällsvetenskaperna utgör ett optimalt fält genom att deras intresseområde nära sammanfaller med det humanekologiska perspektivet. Om något är samhällets interaktiva processer ett tema för sociologi, ekonomi, statsvetenskap, socialpsykologi m. fl. discipliner. Trots detta är klimatet föga gynnsamt för en kreativ humanekologisk ansats. Det viktigaste skälet är de reduktionistiska fördomar som delar av samhällsvetenskapen fortfarande odlar i sin strävan till vetenskaplighet (där den inte landat i postmodernistisk värderelati- vism). Den moderna samhällsforskningen fungerar ofta konserverande på rådande samhällsförhållanden, där den borde vara ifrågasättande och reformivrig. En humanekologisk ansats, kanske under specialbeteckningen «socialekologi», kunde medföra en fördjupning och ett förmänskligande av hela denna sfär. Men det är tveksamt om den ensam förmår leva upp till de kvalitativa krav som är nödvändiga för att ge ett realistiskt bidrag.

Återstår den heterogena grupp av ämnen som brukar presenteras under samlingsbeteckningen «Humaniora». I den positivistiska naturforskningens era utgör de en restpost av discipliner som genom sitt historiska, emotiva och värderelaterade innehåll faller utanför de «sanna» vetenskaperna och därför bedöms som svårhanterliga. Vanligen anses de sakna direkt samhällsnytta, vilket i berörda kretsar ibland ses som en komplimang. Den historie- och faktapositivistiska traditionen har introducerat naturvetenskapens teknik och metodik inom humaniora, men fortfarande anförs det personlighetsdanande draget som det mest karaktäristiska kriteriet. En del humanistiska ämnen har i modern tid försökt undfly det odisciplinerade sällskapet för vetenskapligt stringentare miljöer, t.ex. historieämnet.

En kärna i den humanistiska sfären utgörs av de kulturvetenskapliga disciplinerna, som inkluderar litteraturvetenskap, konstvetenskap, teaterhistoria men också etnologi och aspekter av historia. Det är ämnen som länge värnat om sin integritet genom att odla en historisk och värderelaterad vetenskapsteori, hermeneutiken, som upphöjer kulturyttringarna till exklusiva angelägenheter utom räckhåll för en generell beskrivning i naturvetenskaplig 
PER R $\AA$ B E R G

78 stil. Det tillbakablickande perspektivet dominerar, trots ansatser till modernisering, och bundenheten vid etablerade värdeföreställningar är ganska stor.

Man kan fråga sig vad en framåtblickande och livsdynamisk humanekologi har att hämta i denna krets, som i stort sett är nöjd med sin nisch i vetenskapssamhällets periferi, liksom konsterna med sin trånga nisch i tekniksamhället. Kan vi komma längre bort från de basala krav som en emancipatorisk humanekologi måste ställa på sin vetenskapliga jordmån för att kunna blomstra?

Jag vill faktiskt hävda en rakt motsatt uppfattning. Den tankegång som utvecklats ovan grundar sig på en ytlig värdering av humanioras möjligheter. Kulturvetenskaperna besitter genom sitt djupa kvalitativa intresse en kraftfull potential för en insats efter emancipatoriska principer - och skulle antagligen själva ha mycket att vinna på en anknytning. Jag vill t.o.m. gå så långt att jag påstår att de humanistiska fakulteterna utgör den logiska hemorten för en humanekologisk framtidsforskning efter livsdynamiska principer, särskilt i ett inledningsskede. Jag skall ägna fortsättningen av denna text till att förklara vad jag menar med detta både för traditionell humanekologi och klassisk humaniora provocerande utttalande.

\section{VÄRDEPERSPEKTIVET I CENTRUM}

Utgångspunkten för mitt resonemang är den nyckelroll som ett kvalitativt värdeperspektiv intar i den psyko-ekologiska konstitutionen, hos människan liksom på mer elementära evolutionsstadier. Värdeperspektivet utgör själva centrum $\mathrm{i}$ individens livsmedvetande, liksom detta är centrum för den ekologiska interaktionen mellan organism och omvärld. Värdemedvetandet är hos de enklaste organismerna ett rudimentärt system för att registrera sensoriska intryck från omvärlden och aktivera individen i nutritiva eller reproduktiva syften. Hos människan har det ekologiska värdemedvetandet utvecklats till ett ytterst komplext motivationscentrum, där omvärldens levnadsvärde bedöms utifrån sensoriska, estetiska, sociala och funktionella kriterier som därefter utlöser komplexa aktionsmönster. Värdeperspektivet representerar helt enkelt ekomedvetandets högsta kreativa instans och är i denna roll en avgörande drivkraft för samhällsprocesserna.

Det är ett egendomligt faktum att den systematiska analysen av de högre medvetandeprocesserna (inklusive värdeperspektivet) $\mathrm{i}$ hög grad saknas i det vetenskapliga kultur- och samhällsstudiet $\mathrm{i}$ vår tid. Mellan biovetenskapens neurofysiologi och samhällsvetenskapernas behaviorism finns ett gapande tomrum, som egentligen borde utgöra själva centrum i människo- och samhällsforskningen. Sanningen är att vi måste gå ända till den lilla skaran av humanistiska discipliner för att finna artikulerade studier av medvetandet på den avancerade funktionsnivå som är karaktäristisk för den moderna människan. Dessa studier har oftast tillämpad karaktär och avser andliga och estetiska kulturyttringar inom litteraturen, musiken, konsten etc. Också etnologins vardagslivsstudier och historieforskningens panoramabilder inbegriper de komplexa medvetandeprocesserna, och grenar av filosofin fullföljer en klassisk tradition av självreflektion kring etiska, andliga och existentiella frågor.

Det mesta av detta kunskapsstoff värnar 
man om som subjektivt eller historiskt tankegods och blundar för möjligheten till generella tolkningar. Detta har föranlett kritik från de s. k. objektiva vetenskaperna. Den emancipatoriska ekologin anser för sin del att generella kunskaper är ett viktigt principiellt forskningsmål, men menar inte att den skall sökas till varje pris. Det primära i dagens defensiva kulturklimat måste vara vakthållningen kring de högre medvetandeprocesserna och deras kvalitativa yttringar. Att kulturämnena inte $i$ högre grad fallit för reduktionismens frestelser förtjänar faktiskt en eloge. Inför denna bedrift måste all vetenskapsteoretisk kritik inledningsvis träda tillbaka.

Respekten för de högsta medvetandeprocessernas suveränitet bör vara utgångspunkten också för ekologins samhällsstudium om det vill göra anspråk på epitetet emancipatoriskt. Av detta skäl framstår den humanistiska ämnessfären som den naturliga hemvisten för den radikala humanekologin, trots dess bristande intresse i dagsläget för universella och normativa lösningar. Avgörande är till sist kravet på realism i människo- och samhällsstudiet. Först med en humanistisk fakultetsanknytning hamnar den emancipatoriska humanekologin på jämbördig nivå med sitt studieobjekt: de levande kulturprocesserna i samhället.

Men kan vi också räkna med de nuvarande kulturvetenskapernas intresse för en koalition av det slag som skisseras? Det är ingalunda självklart, med den odling av subjektivitetens ideal som bedrivs här och det måttliga samhällsintresse som kännetecknar ämnesgruppen. Kanske kan dock närmare eftertanke och inte minst insikten om de hot mot den kulturvetenskapliga sfärens existens som det samtida paradigmet representerar (och som krympt sfären till förödmjukande proportioner $\mathrm{i}$ vetenskapernas krets) mildra omdömena från eventuella opponenter och styra in diskussionen på ett konstruktivt spår. En närmare granskning av den emancipatoriska riktningen kan förhoppningsvis visa att den kvalitativa humanekologin kan bli ett aktivt stöd för kulturvetenskaperna och stärka de hotade värden som man förespråkar.

\section{HUMANISTISKA FRAMTIDSSTUDIER}

Men låt oss bli mer konkreta. Vad av värde kan den kvalitativa humanekologin tillföra den humanistiska ämneskretsen? Jag skall inleda med att hänvisa till en humanekologisk experimentverksamhet som bedrivits vid Kollegiet for humanistiska framtidsstudier $i$ Umea under mer än en tioårsperiod. Uppgiften för detta projekt har varit att utforma kunskapsunderlaget för en humananistisk samhällsplanering genom att kartlägga individens ekologiska beteende i dess allmängiltiga drag. På basis av dessa studier, där ett evolutionistiskt perspektiv och de högre medvetandeprocesserna stått i fokus, tecknades en bild av individens ekologiska identitet. Denna bild lades till grund för ett försök att rekonstruera individens ekologiska livsrum, inklusive dess sociala och kulturella zoner. I ett regionalt FoU-projekt testades trovärdigheten i modellen och formulerades ett slagord för den regionalpolitiska debatten, den ekologiska livsregionen. Umeåkollegiets studier har utförligt redovisats $\mathrm{i}$ boken The Life Region. The Social and Cultural Ecology of Sustainable Development (1996). 
80 I Umeåansatsen definieras samhället som ett mänskligt och behovsrelaterat system. Ett holistiskt synsätt appliceras och i den ekologiska interaktionsmodell som tecknas innefattas samtliga relevanta aktionsnivåer. Men ansatsen går längre än så. Den fokuserar särskilt livsmedvetandet, och där i synnerhet det värdeperspektiv som är knutet till medvetandekärnan och är ett centrum för individens existentiella motivation. I projektets modell av ekoidentiteten lokaliserar vi sex konstitutiva värdenivåer, som trots skiftande ursprung alla är uppdaterade till människans avancerade medvetande:

1. Den transcendentala värdenivån. Omfattar individens strävan till universell och andlig identifikation. (Är knuten till naturidentitetens nivå i Umeåmodellens ekoidentitet.)

2. Den empatiska värdenivån. Innefattar strävan till kärleksfull identifikation med avkomman, artfränderna, och ytterst allt levande på planeten. (Knuten till artidentitetens nivå i ekoidentiteten.)

3. Den estetiska värdenivån. Härifrån emanerar önskan om identifikation med omvärldsrummet som en sensorisk skönhetsupplevelse, från mikromiljön och grannskapet till livsregionen och uppåt. (Hänför sig till egonivåns kulturella sektor i ekoidentiteten.)

4. Den sociala värdenivån. Här finner vi strävan till social rättvisa, jämlikhet och demokratiska rättigheter på alla nivåer i samhällsorganisationen. (Egonivåns sociala sektor i ekoidentiteten.)

5. Den funktionella värdenivån. Temat är här strävan till förnuftig teknisk orga- nisation av de mänskliga livsprocesserna, över hela skalan av strukturella aktionsnivåer. (Ego-nivåns instrumentella sektor i ekoidentiteten.)

6. Den logiska värdenivån. Viljan till verifierbara sanningar och kognitiva lagbundenheter i världens uppbyggnad och existensen är drivkraften på denna sista punkt. (Tillhör logoidentitetens nivå i ekoidentiteten.)

Den ekologiska värdehierarkin representerar i Umeåkollegiets modell den överordnade måttstock utifrån vilken vi mäter levnadsvärdet och livskvaliteten i samhället. Det är den mall som människan lägger till grund för sin livsplanering, men också för samhällets organisation, eftersom individens välfärd är det finala målet i ekosamhället. De elementära fysiska och materiella behoven, som vi gör så mycket väsen av i nutiden, träder i den långsiktiga livsplanen tillbaka för värdeperspektivets ideal, men utan att alls försummas i den dagliga livsföringen. Det ekologiska värdeperspektivet representerar ytterst samhällets helhetssyn på den kollektiva existensen. När därför ekonomiska eller teknokratiska eliter tar monopol på helhetsperspektivet och underordnar det sina snäva syften utövar de våld mot människans natur och samhällets ekologiska bas.

\section{DEN KULTUREKOLOGISKA ANSATSEN}

Ur den emancipatoriska ansatsen i Umeå kan vi lyfta fram tre teman som borde intressera kulturvetenskaperna och kunna bidra till att stärka deras positioner. Det första är formuleringen av en nyanserad teori om människans natur, där även de 
EKOLOGI SOM KULTURVETENSKAP

Naturidentitet

Artidentitet

Egoidentitet

Logoidentitet

Efter Raberg 1996: The ecological life-region s. 107.

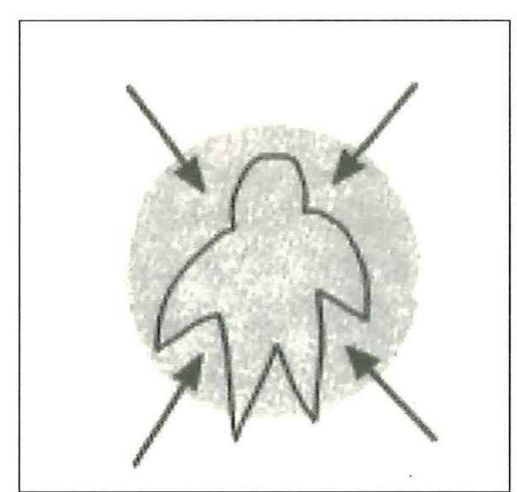

81
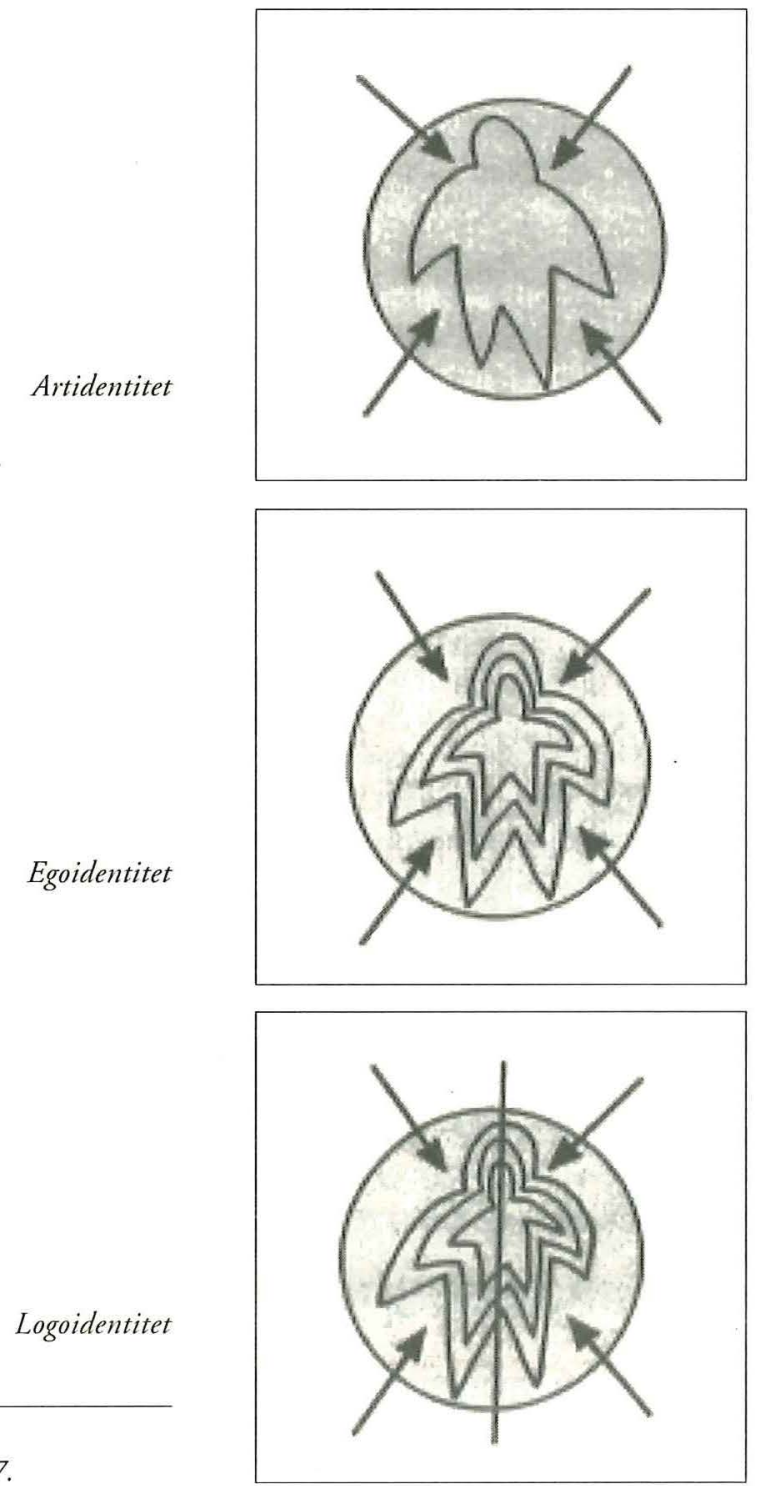
82 högre medvetandeprocesserna och de kulturella behoven definieras. Här finns embryot till en interdisciplinär vetenskap om människan som sträcker sig från evolutionär biologi till avancerad kulturforskning och som kan leda till en ökad förståelse för kulturskapandets villkor både i konsterna och i samhället.

För det andra kan den ekologiska samhällsteorin bidra till att stärka kulturvetenskaperna, både genom sina modeller och teoretiska försök. I den ekologiska teorin hävdas att kulturprocesserna $\mathrm{i}$ ett evolutionsperspektiv tillhör de djupast förankrade mänskliga behoven. Därför måste de beaktas redan på ett tidigt planeringsstadium när de övergripande välfärdsmålen formuleras. Den ekologiska teorin vill vidga kulturpolitikens ansvarsområde till länge förbisedda områden som vardagslivet, stadsplaneringen och kulturlandskapet. Genom dessa omdefinitioner tilldelas kulturvetenskaperna vidsträckta nya verksamhetsfält och ett tidigare okänt medansvar i samhällsprocessen.

För det tredje skapar försöken till en rehabilitering av det existentiella värdeperspektivet förutsättningar för en kulturvetenskaplig renässans. Den fatala förlusten av det kvalitativa värdemedvetandet i vetenskaperna och det politiska tänkandet är kanske det mest alarmerande krisfenomenet av alla i vår tids samhällskris. Att inleda en filosofisk värdediskussion från de radikala utgångspunkterna och samtidigt agera för en tillämpning av kvalitativa livsvärden på olika samhällsnivåer är en uppgift av högsta dignitet. Det är den ultimativa uppgiften för den radikala kulturvetenskap som samhället behöver för att befria sig ur civilisationskrisens trauma.
Låt oss, för att göra en lång historia kort, anta att den emancipatoriska humanekologin på grundval av de anförda meriterna medges inträde i kretsen av kulturvetenskaper vid humanistisk fakultet. Ett namnbyte till beteckningen kulturekologi får markera inträdet $\mathrm{i}$ kretsen. Kulturekologin tilldelas kanske på försök rollen som humanistisk basdisciplin med uppgift att hantera den typ av elementär kulturkunskap som beskrivits ovan. En levande kontakt upprätthålls med de humanistiska specialvetenskaperna, men också med de andra fakulteterna och deras teoretiska perspektiv. På flera sätt som inte skall dryftas här samarbetar disciplinen och de lierade vetenskaperna också med olika aktörer ute i samhället.

Men kulturekologin har också en egen mission att uppfylla, i linje med visionen om en uthållig social och kulturell utveckling. Uppgiften här är att kartlägga människans ekologiska natur som kulturvarelse och agera för att den nya kunskapen läggs till grund för en humanistisk - värdebaserad - samhällsplanering. Detta är genom uppgiftens radikala karaktär ett framtidsorienterat projekt. En intressant fråga är i vad mån de klassiska kulturvetenskaperna kan förmås att engagera sig i ett sådant kunskapssökande och med sina erfarenheter bidra till den nya kunskapens befästande. Historievetenskapen hör till de ämnen som kunde lämna ett viktigt bidrag. T.ex. skulle en kartläggning av den sociala och kulturella desintegrationen i lokalsamhället under det moderna skedet kunna ge värdefulla insikter som omedelbart kunde tillföras framtidsdebatten. Det leder dock för långt att här närmare belysa de möjligheter som öppnar sig inom de enskilda ämnena. 
Redan här vill jag emellertid stanna inför en kulturvetenskaplig ansats som är särskilt ägnad åt att befästa kulturekologiska värderingar i samhället. Jag tänker på den nya museivetenskapen. Skälet till mina förhoppningar är den väsensfrändskap som råder mellan de båda ämnena på en bestämd punkt: deras stora intresse för det lokala livsrummet. För kulturekologin är upprustningen av det omedelbara livsrummet en hjärteangelägenhet när det gäller att skapa ett samhälle med sociokulturell bärkraft. Utvecklingen under moderniteten har ensidigt prioriterat internationalisering och skaltillväxt, vilket som bieffekt har medfört en upplösning och värdeförlust i den sociala samhällskärnan, d.v.s. i den lokala livsmiljön. I kulturekologisk teori uppfattas denna förlust som ett hot mot hela samhällsdynamiken, eftersom den medför en destruktion av själva livsnerven $\mathrm{i}$ de interaktiva processerna. Utformningen av alternativa strategier som inom det nya kosmopolitiska samhället återskapar lokalkulturen och dess värdeinnehåll är en huvudpunkt $i$ en politik för det uthålliga samhället.

\section{"DEEP MUSEOLOGY"}

Museologin är ett bland ganska få ämnen i den akademiska världen som delar detta intresse för den lokala miljön. Den gör det spontant utifrån de konkreta uppgifter som definitionsmässigt utgör museets verksamhetsområde. Museernas främsta uppgift är att samla och exponera kulturartefakter som tillhör människans lokala livssfär. Artefakterna kan härröra från historien eller samtidskulturen, och presentationstekniken varierar, men den tematiska kärnan utgörs av de sinnligt påtagliga föremålen och traditionerna från det omedelbara livsrummet. När den museala verksamheten överskrider det stationära rummets gränser och antar beteckningen kulturmiljö- eller t.o.m. landskapsvård, är det fortfarande närregionens upplevelsevärden som fångar intresset och bildar underlag för åtgärderna. Det finns ingen idémässig motsättning mellan den i snäv mening museala och den yttre kulturvårdande verksamheten.

Inte mindre intressant är att museet också som publikt medium har en påtagligt lokal inriktning. Dess verksamheter är samlade till en specifik arkitektonisk miljö: museiinstitutionen. Museiinstitutionen belyser ofta i sina samlingar det lokala eller regionala samhälle där det har sin hemvist. Mellan innehåll och mediaram råder en sällsynt samstämmighet som har sin grund $\mathrm{i}$ att museet som perceptuell kategori (d.v.s. som receptionsfält i verklighetsförståelsen) tillhör den mänskliga sinneskulturens lokala och stationära dimension. Denna samstämmighet skapar i hög grad den speciella aura som omger många museer. Men till lyskraften hos denna aura bidrar också den dimensionella samstämmighet som existerar mellan museet och det yttre samhällsrum i vars centrum museet intar en plats. På ett närmast självklart sätt spelar museet rollen som en existentiell referenspunkt i lokalsamhället och en katalysator för medborgarnas spontana kulturmedvetande. Man kan hävda att museet oavsiktligt äger en viktig funktion som värdecentrum i det civila samhällslivet.

Det är kanhända djupast på grund av denna existentiella värdegemenskap som museet som publikt medium har lyckats behålla sin position i en modern media- 
PER R \& B R G

84 kultur där informationsteknologins framsteg anger tonen, och där global kommunikation, kognitiv information och snabba scenväxlingar är ledmotiven. Utifrån radikala kommunikationsteoretiska doktriner framstår museets samhällsroll säkerligen i ett annat ljus. Snarare ses museet där som en anakronistisk kvarleva från en svunnen tid, en relikt snart mogen att placeras i något informationskulturens virtuella museum.

Det är knappast djärvt att förmoda att den teknologiska informationskulturens expansion på sikt innebär ett hot mot museiinstitutionen som publikt medium, oavsett vilka förhoppningar som uttrycks idag. Hela kunskapskulturens vridning mot kognitiva ideal och semiologisk förmedling förstärker detta hot. Hoten kommer säkert inte av sig själv att utmynna i någon uppgörelse $\mathrm{i}$ den offentliga debatten, men kan om det vill sig illa leda till nedskärningar som sakta stryper verksamheten.

Vilken hållning skall museimännen men också museivetenskapen - inta till ett scenario som det jag skisserar här? Är kanske det virtuella museet, i princip bestående av en dataskärm i varje stuga och i var forskarcell framtidens melodi? En utveckling i denna riktning har ju redan inletts. Eller är det underhållningsbranschens koncept som representerar den optimala nischen? Onekligen är det ett alternativ som har sina poänger, t.ex. om man vill mäta framgång i besökssiffror. Under alla omständigheter blir det snart nödvändigt för museimännen att välja position i samhällets aktuella förändringsprocess.

Från kulturekologins radikala utsiktspunkt är den samtida hotbilden mot museerna ytterligare ett symtom på den nedmontering av den dynamiska värdekärnan i samhället som pågår, och en beklaglig företeelse med tanke på den stora betydelse som museet äger för många medborgare. Ur dess synvinkel är ett tredje alternativ för museernas vägval mer anslående än de båda förslag som anförts ovan. Det är ett alternativ som antagligen står i bättre samklang med väsenskärnan i museivetenskapen och hos många av de yrkesverksamma inom sektorn. Vad kulturekologin föreslår, är att museerna tvärtemot att revidera sina planer, fördjupar kärnverksamheten och understryker sin mediala karaktär i syfte att axla en helt ny roll: den som nav $i$ en sambällsmobilisering for att upprätta det lokala och regionala livsrummet som existentiellt värdecentrum.

Ur kulturekologins perspektiv är museet långtifrån någon föråldrad institution och ett medium dömt till långsam reträtt. Just genom sin lokala profil och hängivenhet framstår det tvärtom som en kulturinstitution på utvecklingens barrikader, och museologin i konsekvens härav som en avantgardistisk vetenskap. I uppgiften att förverkliga det socialt och kulturellt bärkraftiga samhället kan det bli en slagkraftig partner, både genom sin placering $\mathrm{i}$ lokalsamhällets mitt och sitt radikala budskap till medborgarna.

Men för att ett sådant partnerskap skall fungera måste museet först genomgå en mental omställning som utmynnar i en kristallklar medvetenhet om den paradigmatiska situationen och museets kreativa roll i en önskad samhällsförändring. Startpunkten måste vara att skapa en insikt hos museimännen om museets unika roll som regionalt medium och värnare av det lokala sinnesrummets levnadsvärden. Med stöd av kulturekologins teori kan argu- 
mentationen för dessa värden göras vetenskapligt stringent och ges en tydlig framtidsinriktning. En sak bör understrykas: den dynamiska utgångspunkten är inte museets samlingar utan den institutionella ramen: det slutna och samtidigt öppna museirummet i lokalsamhällets vimmel blir en symbol för den nya värdekultur i mänsklig och samtidigt kosmisk skala som skall iscensättas. Mediafilosofens Marshall McLuhans klassiska slagord "the medium is the message» är värt att återuppliva i detta sammanhang.

Med inspiration från kulturekologins tematik kunde kanske museivetenskapen berikas med Deep Museology, en ny museiideologisk riktning som samlar argumenten för en humanistisk kurs i samhällsutvecklingen och gör museerna till aktionscentra för en bärkraftig lokal och regional kultur. I vetskap om att det livsnära lokalsamhället i balans med sina regionala omgivningar är den nödvändiga grogrunden för balans också i de globala ekosystemen.

\section{LITTERATUR}

Dobson, A., 1994: Green Political Thought.

Routledge, London.

Eckersley, R., 1992: Environmentalism and Political Theory. London.

Human Responsibility and Global Change. Proceedings from the International Conference in Göteborg 1991. University of Göteborg 1992.

Kornblith, H., 1994: Naturalizing Epistemology.

The MIT Press, Cambridge, Mass.

Levine, N.D. (ed.), 1975: Human Ecology. Duxbury

Press, North Scituate, Mass.

Råberg, Per, 1996: The Life Region. The Social and
Cultural Ecology of Sustainable Development.

Acta Universitatis Umensis, Umeå.

Schwerdtfeger, F., 1977: Ökologie der Tiere 1-3.

Verlag Paul Parry, Hamburg.

Spetnak, C. and Capra, F., 1986: Green Politics.

Bear Company, Santa Fe, N.M.

\section{SUMMARY}

Ecology as a humanistic discipline

- a challenge for museums

In the 1970s ecology forcefully entered both public debate and scientific thinking. It caused the 'greening' of politics both nationally and internationally and is slowly making its way into community planning; it has had what could be described as a paradigmatic effect on scientific discourse, primarily in various natural science fields, but also in social sciences. In 'human ecology' however, the emphasis is still placed on the relationship between man and nature. It is necessary to focus more on the human component and to apply ecological knowledge to the socio-cultural environment using individual life-consciousness as a starting point. Only tools appropriated from the value-oriented humanities can be used to deal with the prevalent crisis in the human world. The author argues for an emancipatory human ecology which could, with an anthropocentric understanding of ecology, set about remedying fundamental structural problems in society. So far ecological policies have only managed to deal with very limited areas in community planning. It is a curious fact that the systematic analysis of processes in the human mind and a value-oriented perspective are both lacking in the present study of culture and society. The author refers to a recently published book, The Life Region. The Social and Cultural Ecology of Sustainable Development, where an attempt is made by the Humanist Futurology Group at Umeå University to demonstrate in concrete terms what a value-oriented human ecology 
PER RAB BER

86 could achieve. Three main points are particularly important in the report. First a theory concerning human nature is presented, where both processes in the human consciousness and cultural needs are defined. Secondly the point is made that an ecological approach in social theory could contribute to a strengthening of humanistic models and theoretical work. The third point considered is that attempts to rehabilitate existential value-perspectives could bring about a renaissance in humanistic studies. Museology, which has a multidisciplinary approach in its study of society and cultural heritage as well as a focus on the museum institution and its position at the centre of local communities, could play an important part both in investigating and in communicating knowledge about the ecological dimension both local and global. He advocates the idea of 'deep museology' as a counterpart to 'deep ecology'.

Per Råberg är docent och leder Kollegiet forr humanistiska framtidsstudier. Han är knuten till Institutionen forr museologi vid Umeå universitet.

Adr: Institutionen för museologi, Umea universitet,

S-901 87 Umea

Fax +46-90-166672 